\title{
Influence of Mineral Fertilization and Liming on Maize Production on Argic Chernozem in the Burnas Plain
}

\author{
Anca-Luiza Stănilă (Corresponding author) \\ Department research in soil science, agrochemical and environmental protection \\ Laboratory of soil sciences and sustainable development \\ National Research Institute for Soil Science \\ Agrochemistry and Environment Protection - ICPA \\ 61 Mărăşti Blvd, District 1, 011464, Bucharest, Romania \\ E-mail: luizastanila2011@yahoo.com
}

Received: January 5, 2021 Accepted: February 28, 2021 Published: March 5, 2021

Doi: 10.5296/jab.v9i1.18377ＵRL: https://doi.org/10.5296/jab.v9i1.18377

\begin{abstract}
In order to elucidate some aspects regarding the content of nutrients in the soil or humus, the bioaccumulation and mineralization process of organic matter and correction of the soils reaction in the experimental field, within the agricultural holding SC Orhideea SRL Plopsoru, Locality Daia, Giurgiu County, research has been done with chemical fertilizers with NPK and liming - $\mathrm{Ca}(\mathrm{OH})_{2}$ on argic chernozem in maize culture from the Burnas Plain in different doses.

Obtaining appropriate agricultural production on argic chernozems is limited by a number of factors such as relief, clay loam, low-medium permeability just below the plowed horizon advanced degree of soil compaction, located between 20-35 cm from the surface (plow sole) and climatic conditions.
\end{abstract}

Keywords: Chemical fertilizers, $\mathrm{pH}$ reaction, Variants, Liming, Maize production, Burnas Plain

\section{Introduction}

In order to find out the production potential of soils, it is necessary to know the rate of change of their fertility under the influence of different technological measures, including mineral fertilization and liming $-\mathrm{Ca}(\mathrm{OH})_{2}$. They are obtained maximum crops, when the climate provides the living conditions required by plants. 
Experience in field conditions, provides the most valuable indications on soil fertility, of the effect that fertilizers have on the level and quality of the harvest.

Experience for maize culture (Zea mays), was located in the eastern half of the Burnas Plain, subunit of the Lower Danube Plain, within the agricultural holding SC Orhideea SRL Plopşoru, Locality Daia, Giurgiu County. The locality is located in the south of Giurgiu county, being crossed by the national road DN5, which connects Giurgiu with Bucharest.

Experimental field with an area of $3600 \mathrm{~m}^{2}$ it is represented by a relatively flat relief having an absolute altitude of $90 \mathrm{~m}$ and it is made up of levantine clays over which follows a layer of gravel (Villafranchiene). The stack ends with a loess-like deposit on which the current soil has developed.

The research was developed during the period 1998-1999 without being published. Their publication today after 23 years is welcome and even useful being a landmark for pedological and agrochemical studies.

\section{Materials and Methods}

The pedological and agrochemical mapping was performed at a scale of 1:10.000, using level curves maps and soil map, Giurgiu sheet, scale 1: 200.000. The classification of soils at the level of type, subtype were made in accordance with the "Romanian Soil Taxonomy System (SRTS)", ICPA, 2012.To characterize the physical and chemical were collected numerous soil samples unmodified and modified settlement on which were performed the determinations in the laboratory.

In modified settings, soil samples of $20 \mathrm{~cm}$ thickness were taken in bags, for the chemical characterization to be carried. In natural (unchanged) settings, soil samples were taken using a metal cylinder of known volume $\left(200 \mathrm{~cm}^{3}\right)$ to characterize the physical features, as well as the momentary soil moisture (Stănilă \& Parichi, 2001).

The chemical characteristics were determined using the following methods (Stoica et al., 1986):

pH: potentiometrically, with glass and calomel combined electrode, in aqueous suspension, at the ratio of $1 / 2.5$

Humus: wet oxidation (Walkley-Black method, modified) and results expressed in percentage.

Total nitrogen (Nt): Kjeldahl method, decomposition of $\mathrm{H}_{2} \mathrm{SO}_{4}$ at $350^{\circ} \mathrm{C}$, catalysts: potassium sulphate and copper sulphate.

Available phosphorus (mobile): Egner-Riehm-Domingod method and colorimetric dosed with blue molybdenum, according to Murphy-Riley method (ascorbic acid reduction).

Available potassium (mobile): extraction according to Egner-Riehm-Domingo method and dosing by flame photometry.

Calcium carbonate $\left(\mathbf{C a C O}_{3}\right)$ : is determined by reacting the limestone with $\mathrm{HCl}$ and treating the excess $\mathrm{HCl}$ with $0.5 \mathrm{~N} \mathrm{NaOH}$ solution in the presence of phenolphthalein.

Degree of base saturation (V\%): was determined with the following formula $\mathrm{V}=\mathrm{SB} / \mathrm{T}^{*} 100, \%$ by weight 


\section{Al Macrothink}

Total cation exchange capacity ( $T$ me/100 g soil): was determined with the following formula $\mathrm{T}$ (me/100 $\mathrm{g}$ soil) $\mathrm{T}=\mathrm{SB}+\mathrm{Ah}$

For field crops located on flat land or sloping average size of the sampling agrochemical is from 2 to 5 ha.

The sample average is the agrochemical is a number of partial samples, namely: 25 for uniformly fertilized land.

Partial samples are collected from points arranged in zigzag or parallel directions inside of the harvesting parcel. The depth of the collection is $0-20 \mathrm{~cm}$ arable land. Each sample was partially collected, placed in a box, representing, thus, the average sample agrochemical.

Interpretation of the results has been submitted in accordance with "Methodology developing soil studies", ICPA Bucharest, 1987 provided for in current legislation on the subject.

\section{Results and Discussion}

The experimental field on which the experiment was placed belongs to the Burnas Plain and is characterized by a relatively flat relief, with insignificant unevenness of type saucer $(0.50-0.75 \mathrm{~cm})$ (Posea \& Cruceru, 2005). From a geological point of view, the territory under study has a simple constitution, being made up of levantine clays over which follow the well-known gravels of Fratesti (Villafranchiene) sandy to the surface. The stack is covered with a loess-like deposit 7-8 m thick, rich in $\mathrm{CaCO}_{3}(5-12 \mathrm{~m})$ on account of which most of the region's soils were formed (Figure 1).

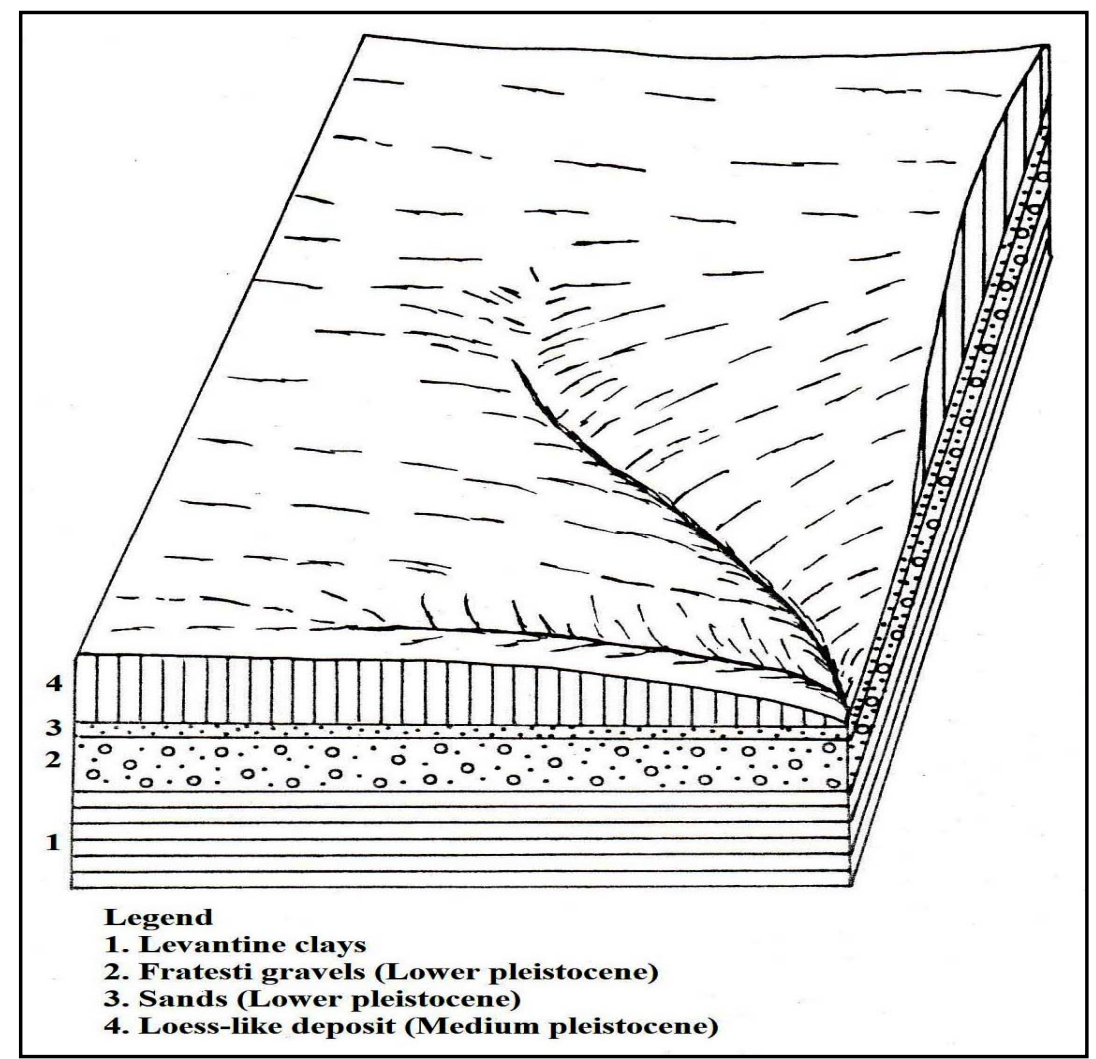

Figure 1. Geological composition of the territory of SC Orhideea SRL Plopșoru, Locality Daia 
In terms of climate, the field and the entire plain zone, it falls in a hot-dry area, with average annual temperatures of $11.3^{\circ} \mathrm{C}$ precipitation of $535 \mathrm{~mm}$ and potential evapotranspiration that can frequently exceed $700 \mathrm{~mm} /$ year.

From the data on the vegetation of our country it appears that the region studied belongs to the steppe zone.

Grass vegetation consists of steppe elements, xerophiles (Stănilă, 2006): Botriochloa ischaeum, Festuca valesiaca, Agropyron cristatum, Poa bulbosa, Artemisia austriaca, Cynodon dactylon, Stipa lessingiana, Stipa capillata, Trifolium pratense, Medicago falcata, Melilotus officinalis.

Wood vegetation appears widespread only in the form of clows consisting of: Quercus pubescens, Quercus pedunculiflora, Tilia tomentosa, Populus alba, Populus tremula, etc.

The groundwater is located at great depths $(20-25 \mathrm{~m})$ and the oscillations of the hydrostatic level are insignificant (1-2 m) and depend mainly on the flows and levels of the two waters (Danube and Calniștea), which bypass the region to the north and south.

Experience in increasing nutrient content in maize cultivation on argic chernozem is stationary, in randomized blocks in three variants, including the control variant, with three repetitions, the surface of the experimental plot being $900 \mathrm{~m}^{2}$ and the surface of the variant of $225 \mathrm{~m}^{2}$ (Figure 2).

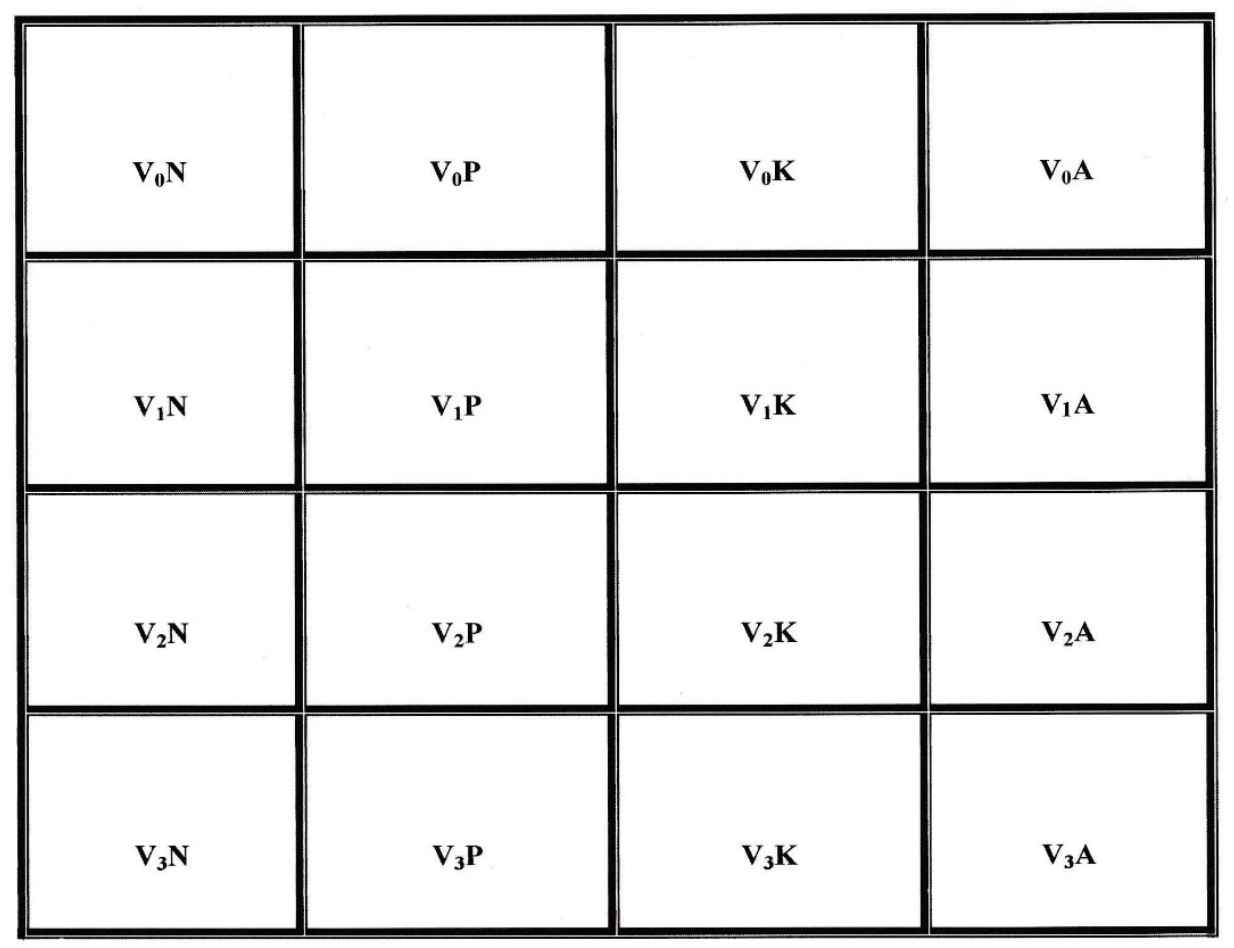

Figure 2. Scheme of the location of the experience in the Burnas Plain:

$\mathrm{V}_{0} \ldots \ldots . \mathrm{V}_{3}-$ Variants

$\mathrm{N}$ - nitrogen; P - phosphorus; $\mathrm{K}$ - potassium; A - liming 
Technological data used in experiments

The plowing was performed with the plow in the unit with the tractor $U$ 650, on 12.11.1998, at $12-15 \mathrm{~cm}$ depth. Sowing was done with SPC-4 at a depth of $5-8 \mathrm{~cm}$ the distance between the rows being $70 \mathrm{~cm}$ and the Fundulea 376 variety was used.

The principle of variation of one was applied using simple fertilizers: ammonium nitrate $(33.5 \% \mathrm{~N})$, diamoniacal phosphate $\left(13-47-0,13 \%\right.$ nitrogen, $\left.47 \% \mathrm{P}_{2} \mathrm{O} 5\right)$, potassium salt $(28-30 \%$ $\left.\mathrm{K}_{2} \mathrm{O}\right)$ and liming $-\mathrm{Ca}(\mathrm{OH})_{2}$.

The technological doses N150, N100, N50 were administered as follows:

Dose N150: $75 \% \mathrm{~N}$ at sowing (07.05.1999), 37.5\% for the first offspring, in turn (01.06.1999) and $37.5 \% \mathrm{~N}$ at the beginning of the panic, one by one (11.07.1999).

Dose N100: $50 \% \mathrm{~N}$ at sowing (07.05.1999), $25 \%$ on the first hatchery in a row $(01.06 .1999)$ and $25 \%$ at the beginning of the panic (11.07.1999).

Dose N50: $25 \%$ at sowing (07.05.1999), $12.5 \%$ on the first brood in a row (01.06.1999) and $12.5 \%$ at the beginning of the panicle (11.07.1999).

The technological doses of P80, P60, P40 were administered at the first mating in a row (01.06.1999).

The technological doses of K50, K35, K20 were administered at the first mating in a row (01.06.1999).

The technological doses of $\mathrm{Ca}(\mathrm{OH})_{2}{ }_{1200}, \mathrm{Ca}(\mathrm{OH})_{2} 600$ and $\mathrm{Ca}(\mathrm{OH})_{2} 300$ were administered by surface spreading (01.06.1999).

\section{Agrochemical condition of soils before NPK fertilization and liming}

One of the main factors that conditions the harvest is the soil and related to it its various properties. As it is known through the soil, plants take water and nutrients from the soil, but man through agrotechnical measures can influence the relationships between these factors and plants. In this case, from the chemical analysis of the surface horizon $(0-30 \mathrm{~cm})$ in the experiment, carried out before the application of fertilizers and liming, showed a weak soil $\mathrm{pH}$ reaction (6.27-6.73) and low-medium humus contents $(2.88-3.10 \%)$ in the fertilized variants with nitrogen; $2.78-3.22 \%$ in the fertilized variants with phosphorus; $2.98-3.38 \%$ in variants fertilized with potassium and predominantly over $3.07-3.36 \%$ in the liming variants (Table 1). The nutrient reserve proved to be low $(0.142-0.146 \%)$ in terms in the nitrogen fertilized variants, very small-medium (6-26 ppm) in fertilized variants with phosphorus; predominantly large in fertilized variants with potassium (170-288 ppm) and in the liming variants high values (28.68-30.66 me $/ 100 \mathrm{~g}$ soil) of the total exchangeable bases and capacity total exchange is medium (33.50-37.62 me /100 g soil).

\section{Changes in soil following NPK fertilization and liming}

The fertilization and liming of the soil in the experimental field produced minor chemical changes. In the following, we briefly show the changes that occurred after fertilization applied during sowing and during vegetation.

When harvesting corn, insignificant increases of the $\mathrm{pH}$ value were found, including in the liming variants (Table 2, Figure 3). 
The humus reserve that was experimented changed significantly only in some variants $\left(\mathrm{V}_{2} \mathrm{~N}\right.$, $\left.\mathrm{V}_{2} \mathrm{P}, \mathrm{V}_{2} \mathrm{~K}\right)$. The increases were higher as the soil had a lower initial reserve. The nitrogen content increased in all variants fertilized with that element $(0.008 \%, 0.014 \%)$, but especially in $\mathrm{V}_{2} \mathrm{~N}$ and $\mathrm{V}_{3} \mathrm{~N}$.

Regarding phosphorus, significant increases are observed only in the case of $\mathrm{V}_{2} \mathrm{P}$. The changes in potassium are not conclusive and this is probably due to the way in which the analyzed sample was constituted or analysis errors. More significant changes are observed with respect to the other chemical properties, in the case of liming variants.

Thus, both SB and T decrease by 1.68-6.42 me /100 $\mathrm{g}$ of soil, in the ascending order of the doses of liming.

Also in the liming variants there are significant increases in the degree of saturation, the highest values $(92.30 \%$ compared to $81.5 \%)$ were observed in the variants in which it was added maximum amount of $\mathrm{Ca}(\mathrm{OH})_{2}$.

\section{Production results}

Experience with doses of fertilizers and liming, aimed to specify the quantity $(\mathrm{kg} / \mathrm{ha})$ at which the highest yield is obtained, as well as that which results in the optimum harvest from an economic point of view. In the field experience organized according to the above scheme, maize production, in general.

Table 1. Agrochemical condition of soils before NPK fertilization and liming

\begin{tabular}{|c|c|c|c|c|c|c|c|c|c|c|c|c|c|c|c|c|}
\hline \multirow{3}{*}{$\begin{array}{l}\text { Chemical } \\
\text { propertie } \\
\text { s }\end{array}$} & \multicolumn{16}{|c|}{ Variants } \\
\hline & $\mathrm{V}_{0} \mathrm{~N}$ & $\mathrm{~V}_{1} \mathrm{~N}$ & $\mathrm{~V}_{2} \mathrm{~N}$ & $\mathrm{~V}_{3} \mathrm{~N}$ & $\mathrm{~V}_{0} \mathrm{P}$ & $\mathrm{V}_{1} \mathrm{P}$ & $\mathrm{V}_{2} \mathrm{P}$ & $\mathrm{V}_{3} \mathrm{P}$ & $\mathrm{V}_{0}$ & $\mathrm{~V}_{1}$ & $\mathrm{~V}_{2}$ & $\mathrm{~V}_{3}$ & $\mathrm{~V}_{0} \mathrm{~A}$ & $\mathrm{~V}_{1} \mathrm{~A}$ & $\mathrm{~V}_{2} \mathrm{~A}$ & $\mathrm{~V}_{3} \mathrm{~A}$ \\
\hline & & & & & & & & & K & $\mathrm{K}$ & $\mathrm{K}$ & $\mathrm{K}$ & & & & \\
\hline \multirow[t]{2}{*}{$\mathrm{pH}\left(\mathrm{H}_{2} \mathrm{O}\right)$} & 6.48 & 6.45 & 6.74 & 6.65 & 6.4 & 6.4 & 6.7 & 6.7 & 6.49 & 6.27 & 6.65 & 6.73 & 6.42 & 6.53 & 6.46 & 6.72 \\
\hline & & & & & 5 & 2 & & 3 & & & & & & & & \\
\hline \multirow[t]{2}{*}{ Humus $\%$} & 2.88 & 3.0 & 2.95 & 3.1 & 3.1 & 2.9 & 2.7 & 3.2 & 2.98 & 3.38 & 3.1 & 3.29 & 3.07 & 3.19 & 3.26 & 3.36 \\
\hline & & & & & 2 & & 8 & 2 & & & & & & & & \\
\hline \multirow[t]{2}{*}{ Ntotal \% } & 0.14 & 0.14 & 0.14 & 0.14 & - & - & - & - & - & - & - & - & - & - & - & - \\
\hline & 2 & 6 & 4 & 6 & & & & & & & & & & & & \\
\hline P ppm & - & - & - & - & 16 & 21 & 6 & 26 & - & - & - & - & - & - & - & - \\
\hline K ppm & - & - & - & - & - & - & - & - & 202 & 220 & 170 & 288 & - & - & - & - \\
\hline $\mathrm{CaCO}_{3}$ & - & - & - & - & - & - & - & - & - & - & - & - & - & - & - & - \\
\hline SB & - & - & - & - & - & - & - & - & - & - & - & - & 28.6 & 29.7 & 28.6 & 30.6 \\
\hline $\mathrm{me} / 100 \mathrm{~g}$ & & & & & & & & & & & & & 8 & 4 & 8 & 6 \\
\hline \multicolumn{17}{|l|}{ sol } \\
\hline $\mathrm{T} \mathrm{me} / 100$ & - & - & - & - & - & - & - & - & - & - & - & - & 33.5 & 35.2 & 35.0 & 37.6 \\
\hline g sol & & & & & & & & & & & & & & & 5 & 2 \\
\hline
\end{tabular}




\section{MInstitute Macrothink $_{\text {Ims }}$}

Table 2. Agrochemical condition of soils after NPK fertilization and liming

\begin{tabular}{|c|c|c|c|c|c|c|c|c|c|c|c|c|c|c|c|c|}
\hline \multirow{2}{*}{$\begin{array}{l}\text { Chemical } \\
\text { properties }\end{array}$} & \multicolumn{16}{|c|}{ Variants } \\
\hline & $\mathrm{V}_{0} \mathrm{~N}$ & $\mathrm{~V}_{1} \mathrm{~N}$ & $\mathrm{~V}_{2} \mathrm{~N}$ & $\mathrm{~V}_{3} \mathrm{~N}$ & $\mathrm{~V}_{0} \mathrm{P}$ & $\mathrm{V}_{1} \mathrm{P}$ & $\mathrm{V}_{2} \mathrm{P}$ & $\mathrm{V}_{3} \mathrm{P}$ & $\mathrm{V}_{0} \mathrm{~K}$ & $\mathrm{~V}_{1} \mathrm{~K}$ & $\mathrm{~V}_{2} \mathrm{~K}$ & $\mathrm{~V}_{3} \mathrm{~K}$ & $\mathrm{~V}_{0} \mathrm{~A}$ & $\mathrm{~V}_{1} \mathrm{~A}$ & $\mathrm{~V}_{2} \mathrm{~A}$ & $\mathrm{~V}_{3} \mathrm{~A}$ \\
\hline $\mathrm{pH}\left(\mathrm{H}_{2} \mathrm{O}\right)$ & 6.56 & 6.5 & 6.42 & 6.3 & 6.5 & 6.36 & 6.54 & 6.38 & 6.28 & 6.4 & 6.48 & 6.34 & 6.3 & 6.36 & 6.26 & 6.3 \\
\hline Humus \% & 3.24 & 3.12 & 3.48 & 3.3 & 3.3 & 3.3 & 3.24 & 3.3 & 3.12 & 3.12 & 3.48 & 3.48 & 3.18 & 3.0 & 3.3 & 3.36 \\
\hline Ntotal \% & 0.14 & 0.154 & 0.158 & 0.16 & - & - & - & - & - & - & - & - & - & - & - & - \\
\hline P ppm & - & - & - & - & 19 & 11 & 26 & 28 & - & - & - & - & - & - & - & - \\
\hline $\mathrm{K}$ ppm & - & - & - & - & - & - & - & - & 214 & 214 & 217 & 226 & - & - & - & - \\
\hline $\mathrm{CaCO}_{3}$ & - & - & - & - & - & - & - & - & - & - & - & - & - & - & - & - \\
\hline $\begin{array}{l}\text { SB me/100 } \\
\text { g sol }\end{array}$ & - & - & - & - & - & - & - & - & - & - & - & - & 26.4 & 27.8 & 27 & 28.8 \\
\hline $\begin{array}{l}\mathrm{T} \text { me/100 } \\
\mathrm{g} \mathrm{sol}\end{array}$ & - & - & - & - & - & - & - & - & - & - & - & - & 30.15 & 31 & 30.75 & 31.2 \\
\hline
\end{tabular}

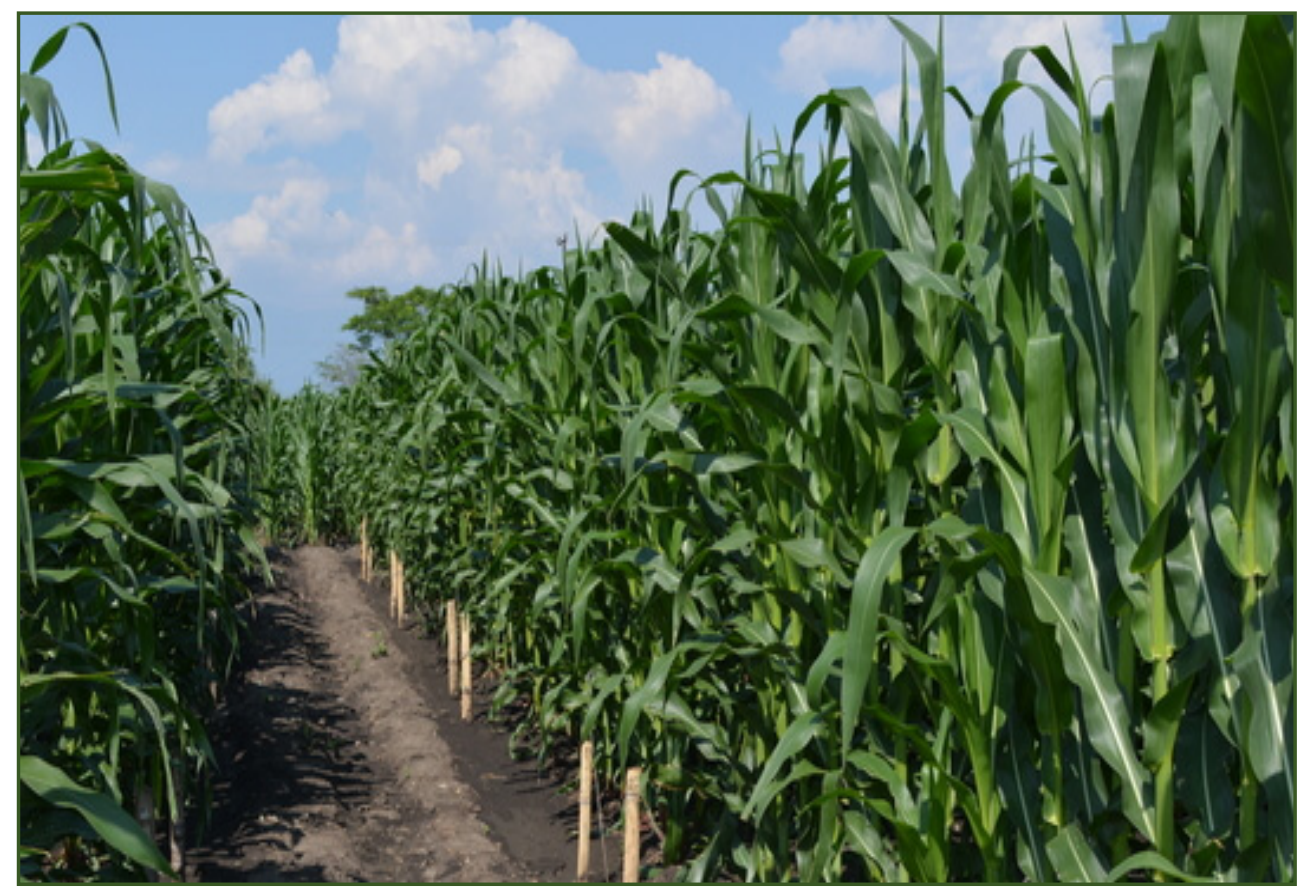

Figure 3. Zea mays culture in the experimental field

In the plot fertilized with ammonium nitrate, it was found that compared to the control variant in which it was obtained $6253 \mathrm{~kg}$ grains/ha, in $\mathrm{V}_{1} \mathrm{~N}_{50}$, the favorable effect of ammonium nitrate brought an increase in production of $241 \mathrm{~kg} / \mathrm{ha}$. Maize production continued to increase with subsequent doses, reaching in the $\mathrm{V}_{3} \mathrm{~N}_{3}$ variant, $6895 \mathrm{~kg} / \mathrm{ha}$, the harvest increase representing $642 \mathrm{~kg} / \mathrm{ha}$ (Table 3). 
Table 3. Efficiency of nitrogen fertilizers on maize production

\begin{tabular}{llll}
\hline Variants & Production (kg/ha) & $\mathbf{\%}$ & Production increase (Kg/ha) \\
\hline $\mathrm{V}_{0} \mathrm{~N}_{0}$ & 6253 & 100 & 0 \\
$\mathrm{~V}_{1} \mathrm{~N}_{50}$ & 6594 & 105 & 241 \\
$\mathrm{~V}_{2} \mathrm{~N}_{100}$ & 6811 & 108 & 558 \\
$\mathrm{~V}_{3} \mathrm{~N}_{150}$ & 6895 & 110 & 642 \\
\hline
\end{tabular}

Of course, the harvest would have been much higher if phosphorus and potassium or a much larger amount of fertilizer had been added, knowing that corn is a major consumer of nitrogen. In the plot fertilized with phosphorus fertilizers, their efficiency was higher $(6970 \mathrm{~kg} / \mathrm{ha})$, starting with the version in which the smallest amount of substance was applied $\left(\mathrm{V}_{1} \mathrm{P}_{40}\right)$.

At the maximum applied dose $\left(\mathrm{V}_{3} \mathrm{P}_{80}\right)$, the production increase exceeded even $2000 \mathrm{~kg}$ of grains/ha. This was also possible due to the fact that the soil already had a supply before the fertilizer was applied good with phosphorus (Table 4).

Tabel 4. Efficiency of phosphorus fertilizers on maize production

\begin{tabular}{llll}
\hline Variants & Production (kg/ha) & \% & Production increase (Kg/ha) \\
\hline $\mathrm{V}_{0} \mathrm{P}_{0}$ & 6162 & 100 & 0 \\
$\mathrm{~V}_{1} \mathrm{P}_{40}$ & 6970 & 113 & 808 \\
$\mathrm{~V}_{2} \mathrm{P}_{60}$ & 7443 & 120 & 1281 \\
$\mathrm{~V}_{3} \mathrm{P}_{80}$ & 8171 & 132 & 2009 \\
\hline
\end{tabular}

Potassium fertilizers applied alone under argic chernozem conditions brought much smaller production increases compared to the phosphorus-fertilized plot, although initially the soil contained large amounts of potassium (170-288 ppm).

The highest production was obtained in the $\mathrm{V}_{3} \mathrm{~K}_{3}$ variant ( $8336 \mathrm{~kg}$ of grains/ha), the increase compared to the control variant $\left(\mathrm{V}_{0} \mathrm{~K}_{1}\right)$ being $1494 \mathrm{~kg} /$ ha (Table 5).

Table 5. Efficiency of potassium fertilizers on maize production

\begin{tabular}{llll}
\hline Variants & Production $\mathbf{( k g / h a )}$ & $\mathbf{\%}$ & Production increase $\mathbf{( K g} / \mathbf{h a})$ \\
\hline $\mathrm{V}_{0} \mathrm{~K}_{0}$ & 6842 & 100 & 0 \\
$\mathrm{~V}_{1} \mathrm{~K}_{20}$ & 7699 & 112 & 857 \\
$\mathrm{~V}_{2} \mathrm{~K}_{35}$ & 8038 & 117 & 1196 \\
$\mathrm{~V}_{3} \mathrm{~K}_{50}$ & 8336 & 121 & 1494 \\
\hline
\end{tabular}


It appears that the high initial presence of potassium in the soil to which those doses were added contributed to the reduction of plant transpiration and thus to water consumption, which favorably influenced production.

On soils with poor reaction, such as the one on which the present experiment was organized, argic chernozem, at least in Romania not much liming were applied. However, the results we obtained, using doses of 300-1200 kg/ha, they entitle us to recommend liming on soils with a weakly acidic $\mathrm{pH}$ reaction.

The effect of our liming has been significant, especially in $\mathrm{V}_{3} \mathrm{~A}_{1200}$ in which the highest maize production was obtained $(9788 \mathrm{~kg} / \mathrm{ha})$, the increase representing over $3500 \mathrm{~kg} / \mathrm{ha}$ (Table 6).

Table 6. Efficiency of liming on maize production

\begin{tabular}{llll}
\hline Variants & Production $\mathbf{( k g / \mathbf { h a } )}$ & $\mathbf{\%}$ & Production increase $\mathbf{( K g} / \mathbf{h a})$ \\
\hline $\mathrm{V}_{0} \mathrm{~A}_{0}$ & 6259 & 100 & 0 \\
$\mathrm{~V}_{1} \mathrm{~A}_{300}$ & 7094 & 113 & 835 \\
$\mathrm{~V}_{2} \mathrm{~A}_{600}$ & 8049 & 128 & 1790 \\
$\mathrm{~V}_{3} \mathrm{~A}_{1200}$ & 9788 & 156 & 3529 \\
\hline
\end{tabular}

\section{Conclusions}

On argic chernozem cultivated with maize and fertilized with progressive doses of NPK, soil fertility in general was positively influenced, in particular, by the slight increase in the content of humus, total nitrogen and phosphorus.

Compared to the control variant, in all three fertilized plots, the production increases were increasing. The most spectacular increases were obtained in the $\mathrm{V}_{3} \mathrm{P}_{80}$ variant $(2009 \mathrm{~kg} / \mathrm{ha})$. Regarding the effect of the liming, this is maximum in the version in which the highest amount of $\mathrm{Ca}(\mathrm{OH})_{2}\left(\mathrm{~V}_{3} \mathrm{~A}_{1200}\right)$ was added.

In addition to the production increase obtained $(3529 \mathrm{~kg} / \mathrm{ha})$ there was an improvement in some chemical properties of the soil, respectively the $\mathrm{pH}$ reaction and the degree of saturation with bases, but a reduction of the cation exchange capacity by $2-6 \%$.

\section{Acknowledgments}

The author thanks Journal of Applied Biotechnology, Macrothink Institute for financial support.

\section{References}

Florea, N., Munteanu, I., Rusu, C., Dumitru, M., Ianoş, Gh., Răducu, Daniela, Rogobete, Gh. \& Țărău, D. (2012). Romanian System of Soil Taxonomy. Sitech Publishing House, Bucharest, 206.

Ispas, Şt. \& Stănilă, Anca-Luiza (2015). Soils Romania. Publisher Valahia University Press, Targoviste, 246. 


\section{Macrothink}

Posea, Gr. \& Cruceru, N. (2005). Geomorphology Romania. Romania for Tomorrow Publishing House, Bucharest, 364.

Răuță, C., Canarache, A. \& Nițu, I. (1985). Guideline on agricultural improvement works. Academy of Agricultural and Forestry Sciences, Bucharest,, 136.

Stănilă, Anca-Luiza \& Parichi, M. (2001). Soil mapping. Romania for Tomorrow Publishing House, Bucharest, 160.

Stănilă, Anca-Luiza \& Parichi, M. (2005). Glossary of soil science. Romania for Tomorrow Publishing House, Bucharest, 108.

Stănilă, Anca-Luiza (2006). Biogeography. Romania for Tomorrow Publishing House, Bucharest, 254.

Stoica, Elena, Răuță, C. \& Florea, N. (1986). Methods for chemical analysis of soil. ICPA, Bucharest, 487.

\section{Copyright Disclaimer}

Copyright reserved by the author(s).

This article is an open-access article distributed under the terms and conditions of the Creative Commons Attribution license (http://creativecommons.org/licenses/by/4.0/). 